\title{
Experimentando a dor de existir
}

Mariângela Alves de Lima

$\mathrm{o}$ introduzir a belíssima adaptação que fez de O livro de Jó, Luís Alberto de Abreu faz questão de enfatizar o caráter profano do teatro. E tem razão. Para a experiência mística ou para a especulação teológica inventamos o templo, o claustro ou um canto qualquer, íntimo e propício ao sagrado. Mesmo assim, ao sair do espetáculo sentimos a tentação de contradizer Abreu.

Parece como inscrever essa experiência no rol de nossas distraçōes noturnas. O que acabamos de experimentar é diferente do que encontramos habitualmente nas casas de espetáculos. Vimos que o teatro pode ser uma forma de expressão reduzida a uma polaridade essencial. Assistimos a um diálogo em estado puro. Jó questiona o criador e as perguntas ecoam pelo espaço entre os atores e o público. O teatro, essencialmente, vive nesse intervalo entre a pergunta e a resposta. Nenhuma circunstância atenua o fato de que temos de seguir $J o ́$, perguntando e aguardando.

Se o leitor percorrer o texto do Antigo Testamento reconhecerá a diferença entre a experiência literária e a teatral. Podemos imprimir à leitura desse doloroso poema o rimo da nossa ansiedade, atravessando o confronto na medida de nossas forças. Não é o que acontecerá no espetáculo. No teatro, os atores nos conduzem pelo espaço dilatando o tempo, fazendo sentir que o drama da existência humana não resume a ignorância do desígnio divino, mas inclui também a espera. A impaciência soma-se ao desejo de contemplar a face benigna de Deus.

Tudo é muito simples neste trabalho. $\mathrm{O}$ hospital onde se instala o espetáculo e a caracterização dos atores são de um simbolismo óbvio. Em um lugar como este, concentra-se todo o sofrimento, físico e moral. Sempre um sofrimento inevitável, estúpido, recaindo equanimente sobre o justo e o pecador. Não há portanto o que decifrar no tipo de tratamento dado à história de Jó. Resta-nos seguir. Sem interpretar as perguntas e reiterações do protagonista. Com sinceridade, clareza e uma evidente adesão emocional ao texto, os intérpretes não precisam recorrer a nenhuma analogia. Cada espectador saberá o que lhe dói mais.

Este é apenas o segundo espetáculo do Teatro da Vertigem. É cedo para inferir uma vocação para a metafísica. De qualquer forma, ao lidar com a temática religiosa, o grupo não reproduz as ingênuas configurações dos anos 70 , quando tudo terminava na harmoniosa ali-

Mariângela Alves de Lima é crítica do jornal O Estado de S. Paulo e pesquisadora. 
ança de todos com tudo. Por isso mesmo as soluções cênicas que encontra são rigorosamente limpas, acéticas, coladas a um significado evi- dente. No mundo judaico-cristão, ao que parece, fazemos questão de saber por quê.

(O Estado de S. Paulo, 09/03/1995)

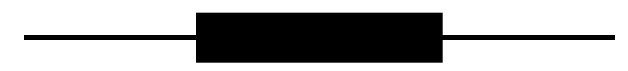

